\title{
UJI KANDUNGAN TIMBAL (Pb) PADA GORENGAN YANG DIJUAL DI PINGGIR JALAN SEPANJANG PANTAI GANDORIAH PARIAMAN SECARA SPEKTROFOTOMETRI SERAPAN ATOM (SSA)
}

\author{
Mega Yulia ${ }^{1}$, Dani Syahrianti ${ }^{2}$, Rahma Yulis ${ }^{3}$ \\ $1,2,3$ \\ Akademi Farmasi Imam Bonjol \\ Email korespondensi : megayuriano@yahoo.com.sg
}

\begin{abstract}
ABSTRAK
Timbal merupakan salah satu unsur logam berat yang terdapat di polusi udara yang dihasilkan bersamaan dengan asap kendaraan bermotor. Timbal dapat menyebabkan berbagai gangguan pada tubuh manusia seperti anemia, kerusakan neurologis, kelainan bentuk dan fungsi tubuh, karies gigi, terganggunya fungsi ginjal, efek pada jantung hingga kemandulan. Timbal dapat masuk ke dalam tubuh manusia melalui udara yang terhirup, melalui kulit serta tertelan bersama dengan makanan. Tujuan penelitian ini adalah untuk mengetahui kandungan timbal dalam jajanan gorengan yang dijual di sekitar Pantai Gandoriah Kota Pariaman. Penelitian ini dilakukan di Laboratorium Baristand (Balai Riset dan Standarisasi Industri) Padang dari bulan Februari - Maret 2020. Penelitian ini dilakukan terhadap 4 sampel yang diambil secara random dari seluruh total populasi. Instrumen yang digunakan adalah spektrofotometri serapan atom (SSA). Hasil penelitian dari ke-4 sampel penelitian menunjukan hasil kandungan timbal pada sala goreng sebesar $0,1618 \mathrm{mg} / \mathrm{kg}$, dengan batas maksimum SNI yaitu $0,3 \mathrm{mg} / \mathrm{kg}$, kepiting goreng sebesar $0,4025 \mathrm{mg} / \mathrm{kg}$, dengan batas maksimum SNI yaitu $0,5 \mathrm{mg} / \mathrm{kg}$, udang goreng sebesar $0,4377 \mathrm{mg} / \mathrm{kg}$, dengan batas maksimum SNI yaitu $0,5 \mathrm{mg} / \mathrm{kg}$, ikan goreng sebesar $0,2331 \mathrm{mg} / \mathrm{kg}$, dengan batas maksimum SNI yaitu $0,3 \mathrm{mg} / \mathrm{kg}$. Berdasarkan hasil penelitian ini dapat disimpulkan bahwa seluruh sampel positif mengandung timbal namun masih berada dibawah ambang batas SNI 7387-2009.
\end{abstract}

Kata kunci: Timbal, Gorengan, Spektrofotometri serapan atom 


\title{
LEAD CONTENT TEST ON FRIED FOODS SALE AROUND GANDORIAH BEACH PARIAMAN USING ATOMIC ABSORPTION SPECTROPHOTOMETRY
}

\begin{abstract}
Lead is one of the heavy metal elements found in the air pollution which is produced together with motor vehicle fumes. Lead can cause various disorders in human body such as anemia, neurological damage, deformities and body functions, dental caries, impaired kidney function, effects on the heart and infertility. Lead can enter the human body through inhaled air, through the skin and ingested with food. The purpose of this study was to determine the lead content in fried foods (fried sala, fried crab, fried shrimp and fried fish) sale around of Gandoriah Beach, Pariaman. This research was conducted at Baristand Laboratory (Research and Standarirdization Industry Center) Padang from February until March 2020. This study was conducted on 4 samples taken randomly from the total population. The instrument used was atomic absorption spectrophotometry (AAS). The results of 4 samples showed that the lead content in fried sala was $0.1618 \mathrm{mg} / \mathrm{kg}$, with a maximum SNI limit is $0.3 \mathrm{mg} / \mathrm{kg}$, fried crab was $0.4025 \mathrm{mg} / \mathrm{kg}$ with a maximum SNI limit is $0,5 \mathrm{mg} / \mathrm{kg}$, fried shrimp was 0.4377 $\mathrm{mg} / \mathrm{kg}$ with a maximum SNI limit is $0.5 \mathrm{mg} / \mathrm{kg}$, fried fish was $0.2331 \mathrm{mg} / \mathrm{kg}$ with an SNI maximum limit is $0.3 \mathrm{mg} / \mathrm{kg}$. Based on the results of this study, it can be concluded all samples contain lead but the level is still below of maximum limit of SNI 7387-2009.
\end{abstract}

Keywords : Lead, fried foods, atomic absorption spectrophotometer

\section{PENDAHULUAN}

Makanan merupakan salah satu bagian penting untuk kesehatan dan kebutuhan manusia. Salah satu makanan favorit bagi masyarakat Indonesia adalah gorengan. Gorengan menjadi pilihan masyarakat selain harganya yang murah, enak, mudah didapat, juga dapat memberikan asupan energi. Namun, pada kenyataannya belum banyak yang mengetahui keamanan gorengan tersebut untuk dikonsumsi. Salah satu hal terpenting dalam memastikan keamanan makanan

yang dikonsumsi adalah harus mencegah makanan tersebut terkontaminasi dari cemaran seperti cemaran biologi, kimia dan benda lain yang dapat mengganggu, merugikan dan membahayakan kesehatan manusia (BPOM, 2020).

Salah satu pencemar yang dapat mengkontaminasi makanan adalah Logam Timbal $(\mathrm{Pb})$. Timbal dapat mengkontaminasi makanan karena makanan tersebut dijual dalam keadaan terbuka ditepi jalan. Timbal dihasilkan dari emisi kendaraan bermotor. Selain timbal zat lain yang diemisikan dari knalpot kendaraan bermotor adalah 
$\mathrm{CO} 2, \mathrm{CO}, \mathrm{NO}, \mathrm{NO} 2 \mathrm{HC}, \mathrm{SO} 2$, dan partikel udara dalam wujud padat yang berdiamater kurang dari 10 mikrometer yang biasanya disebut dengan PM10 (particulate matter) (Anonim, 2020). Menurut Environment Project Agency, sekitar 25\% logam berat timbal $(\mathrm{Pb})$ tetap berada dalam mesin dan $75 \%$ lainnya akan mencemari udara sebagai asap knalpot. Emisi Pb dari gas buangan tetap akan menimbulkan pencemaran udara dimanapun kendaraan itu berada, tahapannya adalah sebagai berikut: sebanyak $10 \%$ akan mencemari lokasi dalam radius kurang dari $100 \mathrm{~m}, 5 \%$ akan mencemari lokasi dalam radius 20 $\mathrm{km}$, dan 35\% lainnya terbawa atmosfer dalam jarak yang cukup jauh (Surani, 2002).

Beberapa studi mengenai analisa kandungan timbal pada makanan yang dijual ditepi jalan telah dilakukan. Ihsan, dkk yang melakukan penelitian mengenai kandungan timbal pada jajanan didepan SD di Kota Padang mendapatkan hasil bahwa kandungan timbal pada makanan tersebut melebihi batas maksimum kadar timbal yang ditetapkan oleh Badan Pengawas Obat dan Makanan (BPOM) dan standar SNI. Novita, dkk yang melakukan penelitian mengenai cemaran timbal pada buah pir yang dijual ditepi jalan simpang empat kota Pekanbaru juga mendapatkan hasil bahwa semua sampel berada diatas ambang batas maksimum cemaran logam berat timbal dalam bahan pangan khususnya buah dan sayur yang ditetapkan berdasarkan BPOM Nomor HK.00.06.1.52.4011. Adapun faktor lain yang berkaitan dengan cemaran timbal pada makanan yang dijual ditepi jalan berkaitan dengan jarak pajanan, lama pajanan, dan penyajian (Restiani et al., 2020). Dampak timbal bagi kesehatan tubuh manusia adalah timbal dapat merusak berbagai organ, terutama organ yang berkaitan dengan sistem saraf, sistem pembentukan darah, sistem jantung, sistem reproduksi dan ginjal. Timbal juga dapat menyebabkan tekanan darah tinggi dan anemia (Amaral et al., 2010).

Pantai Gandoriah merupakan salah satu objek wisata di Sumatera Barat yang selalu ramai dikunjungi oleh wisatawan, baik lokal maupun asing. Ramainya wisatawan ini sebanding dengan meningkatnya kepadatan lalu lintas di sekitar pantai tersebut. Hal ini memungkinkan gorengan seafood yang menjadi ciri khas pantai ini yang banyak pinggir jalan tanpa ditutup terkontaminasi oleh timbal yang dihasilkan oleh kendaraan bermotor Apalagi jarak lokasi pedagang dengan tepi jalan yang hanya 3-6 meter menyebabkan resiko tercemar semakin besar. Besarnya resiko cemaran logam berat timbal yang terkandung pada jajanan terutama yang dijual di pinggir jalan, maka perlu dilakukan penelitian lebih lanjut terhadap kontaminasi logam berat tersebut. Berdasarkan uraian diatas dilakukan penelitian tentang uji kandungan timbal pada gorengan yang dijual di pinggir jalan di sepanjang Pantai Gandoriah Kota Pariaman dengan mengambil 4 sampel secara acak, diantaranya yaitu sala goreng, ikan goreng, udang goreng, dan kepiting goreng, kemudian di uji di Laboratorium Baristand (Balai Riset dan Standarisasi) Industri Padang. 


\section{METODE PENELITIAN}

Penelitian ini dilakukan dari bulan Februari sampai Maret 2020. Penelitian ini adalah penelitian jenis deskriptif untuk mengetahui kadar timbal pada gorengan: sala goreng, kepiting goreng, udang goreng dan ikan goreng yang dijual disekitar pantai Gandoriah Kota Pariaman. Sampel diambil secara acak sederhana yaitu sebanyak 4 sampel dari total populasi yang terdiri dari kelompok jenis yang berbeda. Sampel kemudian diperiksa secara kualitatif menggunakan metode spektrofotometri serapan atom di Balai Riset dan

Standarisasi (Baristand) Industri Padang, Sumatera Barat. Hasil

pemeriksaan kandungan timbal kemudian akan dibandingkan dengan batas maksimum cemaran logam sesuai standar SNI 7387-2009 tentang batas maksimum cemaran logam berat dalam pangan yang bertujuan untuk mengetahui apakah gorengan tersebut masih memenuhi syarat untuk dikonsumsi.

\section{Bahan}

Larutan dari 4 sampel, larutan standar unsur $\mathrm{Pb}, \mathrm{HNO}_{3}, \mathrm{TBP}$, Hexane, air bebas mineral.

\section{Alat}

Seperangkat alat spektrofotometer serapan atom, corong pemisah, hotplate, pengaduk magnet dan peralatan gelas.

\section{Cara Keja}

A. Preparasi untuk kalibrasi

1. Dibuat larutan standar $\mathrm{Pb}$.

2. Larutan standar diukur absorbansinya dengan parameter yang optimum menggunakan AAS.

\section{B. Preparasi sampel}

1. Larutan sampel diuapkan hingga hampir kering kemudian ditambahkan $\mathrm{HNO}_{3}$ pekat dan diuapkan lagi, selanjutnya ditambahkan air bebas mineral dan diuapkan lagi selanjutnya ditambahkan air bebas mineral dan diuapkan sampai hampir kering.

2. Larutan hasil penguapan tersebut dimasukan ke labu ukur danvolumenyaditepatkan sampai tanda batas menggunakan $\mathrm{HNO}_{3}$.

3. Larutan diekstraksi dengan TBP : heksane, kemudian fasa air dipisahkan.

4. Larutan fasa air kemudian diukur absorbansinya menggunakan AAS dengan parameter-parameter yang optimum.

\section{HASIL DAN PEMBAHASAN}

Dari penelitian kandungan Timbal $(\mathrm{Pb})$ pada gorengan yang dijual disekitar Pantai Gandoriah Kota Pariaman secara Spektrofotometri Serapan Atom yang dilakukan terhadap 4 sampel yang diperoleh secara acak dan diujikan di Baristand Industri Padang maka diperoleh hasil kandungan :

1. Sampel 1 (sala goreng) mengandung timbal 0,1618 $\mathrm{mg} / \mathrm{kg}$ dengan batas maksimum SNI 0,3 mg/kg.

2. Sampel 2 (Ikan goreng) mengandung timbal 0,2331 $\mathrm{mg} / \mathrm{kg}$ dengan batas maksimum SNI 0,3 mg/kg. 
3. Sampel 3 (Kepiting goreng) mengandung timbal 0,4025 $\mathrm{mg} / \mathrm{kg}$ dengan batas maksimum SNI $0,5 \mathrm{mg} / \mathrm{kg}$.

4. Sampel 4 (Udang goreng) mengandung timbal 0,4377 $\mathrm{mg} / \mathrm{kg}$ dengan batas maksimum SNI $0,5 \mathrm{mg} / \mathrm{kg}$.

Berdasarkan hasil penelitian tersebut maka dapat disimpulkan bahwa dari 4 sampel yang diujikan didapatkan hasil bahwa adanya kandungan timbal $(\mathrm{Pb})$ pada semua sampel namun

kadarnya masih dibawah batas maksimal yang ditetapkan SNI 73872009 tentang batas maksimum cemaran logam berat dalam pangan. Sehingga dapat dinyatakan bahwa makanan tersebut masih aman untuk dikonsumsi masyarakat, karena kandungan logam timbal yang tidak melebihi standar maksimum SNI.

Pada penelitian ini alat yang digunakan adalah spektrofotometri serapan atom (AAS). AAS merupakan suatu metoda yang digunakan untuk menentukan unsur-unsur dalam suatu sampel/ cuplikan yang berbentuk larutan. Prinsip dari analisis dengan AAS ini didasarkan proses penyerapan energi oleh atom-atom yang berada pada tingkat tenaga dasar (ground state). Penyerapan energi tersebut akan mengakibatkan tereksitasinya elektron dalam kulit atom ke tingkat tenaga yang lebih tinggi (exited state). Akibat dari proses penyerapan radiasi tersebut

elektron dari atom-atom bebas bereksitasi ini tidak stabil dan akan kembali ke keadaan semula disertai dengan memancarkan energi radiasi dengan panjang gelombang tertentu dan karakteristik untuk setiap unsur (Torowati dkk, 2008).

Beberapa faktor dapat mempengaruhi kandungan timbal dalam makanan diantaranya proses penggorengan, makanan yang tidak ditutup, lama pajanan makanan dan jarak pedagang dari badan jalan. Proses penggorengan memungkinkan minyak goreng ikut termakan bersama gorengan dan asap kendaraan bermotor dapat menempel pada minyak goreng karena sifat timbal $(\mathrm{Pb})$ yang lipofilik. Salah satu faktor keberadaan timbal pada minyak goreng adalah penjual tidak menggunakan minyak goreng sesuai standar SNI serta menggunakan minyak goreng secara berulang-ulang. Berdasarkan hasil penelitian Restiani dkk, 2020 diketahui sebanyak 63.3\% pedagang memiliki pengunaan minyak goreng yang kurang baik seperti penggunaan minyak curah, pergantian minyak goreng yang jarang dilakukan dan hanya menambahkan minyak saja, serta tidak adanya penghalang wajan yang menutupi wajan penggorengan dari paparan timbal. Abdul dkk juga mendapatkan hasil adanya perbedaan kandungan timbal pada minyak goreng sebelum dan sesudah penggorengan yang digunakan pedagang gorengan di Lingkungan sam Ratulangi Manado. Hal ini terjadi karena pedagang yang masih menggunakan minyak goreng lebih dari 2 hari sebelumnya (Abdul, 2014).

Marbun dkk, 2010 dalam penelitiannya mengemukakan bahwa salah satu penyebab peningkatan kadar timbal $(\mathrm{Pb})$ pada makanan jajanan yang 
dijual dipinggir jalan Pasar I Padang Bulan Medan tahun 2009 adalah makanan yang dijual dalam keadaan terbuka atau tanpa penutup. Hasil

penelitiannya menunjukan bahwa kandungan timbal pada jajanan mengalami peningkatan hampir $2 \mathrm{x}$ lipat dari awal selesai penggorengan dengan jajanan yang telah dibiarkan 3 jam dan 6 jam setelah digoreng tanpa penutup, dimana saat diangkat dari penggorengan kandungan timbal 0,4287 ppm, 3 jam setelah penggorengan $0,8398 \mathrm{ppm}$ dan 6 jam setelah penggorengan kandungan timbalnya 1,1197 ppm. Hal ini dapat menunjukan juga bahwa lama pajanan dapat meningkatkan kandungan cemaran timbal dalam jajanan. Hasil observasi Perdana dkk, 2017 bahwa sampel udang yang dijual di Pasar Ulakan Tapakis Padang Pariaman yang positif mengandung logam timbal bisa disebabkan karena pedagang yang berjualan pada lokasi yang sangat dekat dengan jalan raya dan hampir tidak ada jarak antara lokasi berjualan dengan tepi jalan. Ditambah lagi kondisi barang dagangan yang dijajakan dalam kondisi terbuka tanpa penutup. Hal ini akan

mempermudah jajanan tersebut tercemar oleh timbal dari asap kendaraan bermotor yang melintasi daerah tersebut.

Jarak pedagang dengan badan jalan juga mempengaruhi kandungan timbal yang ada pada makanan yang dijual. Berdasarkan penelitian Zakaria, 2014, dimana setiap 70\% timbal didalam bahan bakar bensin kendaraan yang diemisikan ke udara akan terdeposit dalam jarak 100 meter dari jalan raya. Semakin dekat jarak sampel dengan sumber pencemar, maka sampel akan tercemar lebih besar. Sebaliknya semakin jauh jarak sampel dari sumber pencemar maka semakin rendah konsentrasi cemaran timbal yang terukur.

Salah satu cara mencegah pencemaran kadar timbal $(\mathrm{Pb})$ dalam makanan yang disajikan pada kawasan traffic light adalah menggunakan penutup. Dengan adanya penutup tersebut, makanan akan terlindung dari asap kendaraan bermotor (Yuliarti, 2007). Makanan yang dibungkus rapat dan dijual di tempat yang tidak banyak dilewati kendaraan bermotor, akan lebih aman di konsumsi. Walaupun kandungan timbal dalam makanan masih dibawah batas maksimal SNI namun konsumsi dalam jumlah besar dan dalam jangka waktu yang panjang harus berhati-hati mengingat sifat timbal yang dapat terakumulasi dan mengendap di dalam tubuh yang dapat menimbulkan hipertensi, kerusakan ginjal, imunotoksisitas dan racun untuk sistem reproduksi. Anak-anak lebih rentan mendapatkan efek buruk dari kontaminasi timbal, dimana timbal dapat merusak sistem saraf walau tidak memberikan gejala yang jelas. Kontaminasi timbal pada anak dapat menyebabkan penurunan kemampuan berpikir, dyslexia atau kesulitan membaca, penurunan konsentrasi dan perilaku antisosial (WHO, 2017).

\section{KESIMPULAN}

Dari hasil analisis yang telah dilakukan, dapat disimpulkan bahwa dari 4 (empat) sampel gorengan yang dijual disekitar Pantai Gandoriah Kota 
Pariaman yaitu sala goreng, kepiting goreng, udang goreng, dan ikan goreng, semuanya positif mengandung logam timbal, namun kandungan logam timbal tersebut masih berada dibawah standar maksimum SNI 7387-2009.

\section{UCAPAN TERIMAKASIH}

Pada kesempatan ini, peneliti ingin mengucapkan terima kasih kepada berbagai pihak yang telah membantu terwujudnya penelitian ini yaitu Akademi Farmasi Imam Bonjol.

\section{DAFTAR PUSTAKA}

Abdul VL, Janno B \& Paul K. (2014).

$\begin{array}{lr}\text { Perbandingan } & \text { Kandungan } \\ \text { Timbal }(\mathrm{Pb}) \text { Pada } & \text { Minyak } \\ \text { Sebelum dan } & \text { Sesudah } \\ \text { Penggorengan } & \text { yang } \\ \text { digunakan oleh } & \text { Pedagang } \\ \text { Gorengan Di Lingkungan } \\ \text { Universitas Sam Ratulangi } \\ \text { Manado.Jurnal Veybbe. }\end{array}$

Anonim. (2020). Dampak Emisi Kendaraan Bermotor dan Lainnya. Diakses dari www.dishub.pemkomedan.go.i d tanggal 8 Desember 2020.

Amaral JH, Rezonde VB, Quintana SM, Gerlach RF,Barbosa F, Tanus.

(2010). The Relationship Between Blood and Serum Lead Levels In Peripartum Woman and Their Respective Umbilical Cords. Basic and Clinical Pharmacology and Toxicology, 107 (6), 971-5.
Badan Pengawas Obat dan Makanan. (2020). Keamanan Pangan Untuk Indonesia Sehat. Diakeses dari www.pom.go.id tanggal 8 Desember 2020.

Ihsan T, Tivany E \& Elsa F. (2018). Lead $(\mathrm{Pb})$ Contamination in Street Vendors Fried Foods in School Area of Padang Municipality Indonesia. International Journal of Advanced Research (IJAR), 6(3), 341-346.

Marbun N.B. (2010). Analisis Kadar Timbal $(\mathrm{Pb})$ Pada Makanan Jajanan Berdasarkan Lama Waktu Pajanan yang Dijual di pinggir jalan Pasar I Padang Bulan Medan Tahun 2009.

Repositori Institusi Universitas Sumatera Utara.

Novita L, Esthy RA \& Aisyah. (2013). Analisis Cemaran Logam Timbal (Pb) Pada Buah Pir yang Dijual di Pinggir Jalan Simpang Empat Lampu Merah Jalan Soekarno Hatta Kota Pekanbaru. Jurnal Proteksi Kesehatan, 6 (1).

Perdana AP, Elmatris Sy \& Eti Y. (2017). Analisis Kandungan Timbal Pada Gorengan yang Dijual Sekitar Pasar Ulakan Tapakis Padang Pariaman Secara Spektrofotometri Serapan Atom. Jurnal Kesehatan Andalas, 6(3), 490494. 
Restiani DD, Dwi S \& Retno H. (2020). Studi Keberadaan Cemaran Formalin dan Timbal pada Tahu yang Dijual Pedagang Gorengan Tahu Petis di Sekitar Kampus UNDIP. Jurnal Epidemiologi Kesehatan Komunitas, 5(1) , 47-56.

Surani R. (2002). Pencemaran dan Toksikologi Logam Berat. Gadjah Mada University Press, Yogyakarta.

Torowati, Asminar dan Rahmiati. (2008). Analisis Unsur $\mathrm{Pb}, \mathrm{Ni}$ dan $\mathrm{Cu}$ Dalam Larutan

Uranium Hasil Stripping Efluen Uranium Bidang Bahan Bakar Nuklir. Jurnal Batan, 02, ISSN 1979-2409.
Undang-Undang Nomor 7 Tahun 1996 tentang Pangan.

World Health Organization. (2017). Quetions and Answers : International Lead Poisoning Prevention Awareness Campaign Week of Action 2228 October 2017. www.who.int diakses tanggal 12 Desember 2020.

Yuliarti N. (2007). Awas Bahaya Dibalik Lezatnya Makanan. CV. Andi Offset, Yogyakarta.

Zakaria. (2014). Analisis Kandungan Logam timmbal $(\mathrm{Pb})$ pada Pangan Jajanan di SDN Kompleks Lariangbangi Kota Makassar. Universitas Hasanuddin, Sulawesi Selatan. 